\title{
ANALISIS KEPEMIMPINAN TERHADAP KINERJA TENAGA KEPENDIDIKAN UNIVERSITAS BUANA PERJUANGAN KARAWANG
}

\author{
Aji Tuhagana ${ }^{1}$, Syifa Pramudita Faddila ${ }^{2}$ \\ aii.tuhagana@ubpkarawang.ac.id \\ syifa.pramudita@ubpkarawang.ac.id \\ Universitas Buana Perjuangan Karawang
}

Jl. HS.Ronggo Waluyo, Timur, Karawang, Jawa Barat 41361

\begin{abstract}
Abstrak
Tujuan penelitian ini adalah untuk menganalis kepemimpinan terhadap kinerja tenaga kependidikan. Cara seorang pimpinan dalam memimpin sebuah organisasi dalam hal ini lembaga pendidikan dapat memberikan warna tersendiri terhadap suasana lingkungan kerja yang dapat dirasakan secara langsung oleh seluruh karyawan (tenaga kependidikan). Hal tersebut dapat terjadi karena di dalamnya terjadi interaksi secara terus menerus antara pimpinan dan yang dipimpinnya (bawahan). Dari interaksi yang terjadi, akan memberikan efek dan pengaruh pada suasana kerja yang dirasakan secara langsung oleh bawahnnya dan akan berimbas pada kinerja yang dapat bernilai positif dan juga negatif tergantung bagaimana cara seorang pemimpin memimpin bawahannya. Fenomena tersebut dirasakan pula di tempat penelitian yakni Universitas Buana Perjuangan Karawang. Penelitian ini menggunakan metode kuantitatif dan diolah menggunakan aplikasi SPSS. Teknik pengumpulan data dengan melalukan wawancara dan penyebaran angket kepada seluruh tenaga kependididikan di tempat penelitian. Hasil penelitian menunjukkan bahwa didapatkan antara variabel kepemimpinan dengan kinerja tenaga kependidikan menunjukkan hubungan yang sangat rendah $(0,366)$ dan berpola positif, didapatkan pula nilai koefisien determinasi $\left(R^{2}\right)=0,134$ yang artinya variabel kepemimpinan menjelaskan kinerja tenaga kependidikan sebesar 13,4\%, sedangkan sisanya dipengaruhi oleh variabel lain diluar penelitian ini. Hasil uji statistik didapatkan ada hubungan antara kepemimpinan terhadap kinerja tenaga kependidikan (P-value $<0,05)$. Persamaan regresi linier pada penelitian ini adalah $\mathrm{Y}=31,832+0,374 \mathrm{X}$.
\end{abstract}


Kata Kunci: Kepemimpinan, Kinerja Tenaga Kependidikan

\begin{abstract}
The purpose of this study is to analyze the leadership style of the performance of educational staff. The style of a leader in leading an organization in this case educational institutions can provide its own color to the atmosphere of the work environment that can be felt directly by all employees (educational staff). This can occur because in it there is continuous interaction between the leader and the leader (subordinate). From the interactions that occur, it will give a very strong effect and influence on the work atmosphere that is felt directly by his subordinates and will impact on performance that can be positive and also negative depending on how a leader leads his subordinates. The phenomenon that occurs above, will also be felt at the research site, Buana Perjuangan University, Karawang. Therefore, the author will conduct research in that field to analyze the leadership style that exists in the research site and its effect on the performance of the education staff at Buana Perjuangan University in Karawang. To complete this study, the authors used a quantitative method and statistical data processing using the SPSS application. Data collection techniques were carried out by conducting interviews and distributing questionnaires to all education personnel at the research site. The results showed that the leadership variable with the performance of educational staff showed a very low relationship (0.366) and positive patterned, also the coefficient of determination $(R 2)=0.134$, which means that the leadership variable explained the performance of the teaching staff by 13.4\%, while the rest influenced by other variables outside this study. Statistical test results found that there is a relationship between leadership and the performance of the teaching staff ( $P$-value $<0.05)$. The linear regression equation in this study is $Y=31.832+0.374 X$.
\end{abstract}


Keywords: Leadership, Performance of Educational Personnel

\section{Latar Belakang}

Dalam sebuah organisasi, baik itu institusi pemerintah ataupun swasta dan juga lembaga pendidikan, dalam segi pengelolaannya di dalamnya terdapat berbagai pihak yang saling terkait yang tidak dapat dipisahkan Antara yang satu dengan yang lainnya yaitu antara lain pemimpin sebagai atasan, dan pegawai atau karyawan sebagai bawahan. Keberadaan seorang pemimpin mutlak diperlukan karena pemimpin memiliki peran strategis dalam usaha mencapai tujuan organisasi sesuai dengan visi, misi dan tujuan organisasi. Maju dan berkembangnya sebuah organisasi ataupun lembaga pendidikan terletak pada bagaimana cara seorang pemimpin memimpin bawahannya. Dan demikian juga bawahan memiliki peran yang strategis dalam melaksanakan seluruh aspek pengelolaan organisasi atau lembaga pendidikan.

Siagian (2002) yang dikutip dalam Madani jurnal Politik dan Sosial Kemasyarakatan oleh Burhanudin Mukhamad Faturahman mengutarakan bahwa Kepemimpinan merupakan individu yang menduduki suatu jabatan tertentu di mana individu tersebut memiliki kemampuan dan keterampilan untuk mempengaruhi perilaku orang lain yakni bawahannya untuk berfikir dan bertindak sehingga melalui perilaku yang positif tersebut dapat memberikan kontribusi dalam pencapaian tujuan organisasi (https://media.neliti.com/media/publications/256948-kepemimpinan-dalam-budaya organisasi-8826321c.pdf).

Dalam lembaga pendidikan, ada dua sebutan yang saling erat kaitannya dalam pengelolaan lembaga yaitu tenaga pendidik dan tenaga kependidikan. Tenaga Pendidik merupakan tenaga profesional yang bertugas merencanakan dan melaksanakan proses pembelajaran, menilai hasil pembelajaran, melakukan pembimbingan dan pelatihan, serta melakukan penelitian dan pengabdian kepada masyarakat, terutama bagi pendidik pada 
perguruan tinggi (UU No.20 Tahun 2003, Pasal 39 (2)). Tenaga kependidikan adalah anggota masyarakat yang mengabdikan diri dan diangkat untuk menunjang penyelenggaraan pendidikan (UU No. 20 tahun 2003 pasal 1, Bab 1 Ketentuan umum). Tenaga Kependidikan merupakan tenaga yang bertugas merencanakan dan melaksanakan administrasi, pengelolaan, pengembangan, pengawasan, dan pelayanan teknis untuk menunjang proses pendidikan pada satuan pendidikan (UU No.20 Tahun 2003, Pasal 39 (1)).

Universitas Buana Perjuangan Karawang adalah merupakan sebuah lembaga pendidikan tingga di kabupaten Karawang yang berdiri dan mendapatkan ijin operasional penyelenggaraan sejak tahun 2014 berdasarkan SK dari Menteri Pendidikan dan Kebudayaan RI Nomor 611/E/O/2014 tanggal 17 Oktober 2014 tentang Izin Pendirian Universitas Buana perjuangan Karawang dan baru menerima pendaftaran mahasiswa baru pada tahun akademik 2015/2016.

Dari sejak berdiri sampai sekarang (2019), universitas Buana Perjuangan Karawang sudah memiliki tenaga kependidikan sebanyak 41 orang sebagaimana terlihat pada data tabel di bawah ini:

Tabel 1.1

Data Tenaga Kependidikan Universitas Buana Perjuangan

\begin{tabular}{|l|c|}
\hline \multicolumn{1}{|c|}{ Bagian } & Jumlah \\
\hline Lembaga & 2 \\
\hline Akademik & 3 \\
\hline LPPM & 2 \\
\hline TU & 9 \\
\hline Kauangan & 4 \\
\hline Umum \& Kepegawaian & 3 \\
\hline Perpustakaan & 4 \\
\hline Pusdatin & 4 \\
\hline Kemahasiswaan & 2 \\
\hline LP3M & 2 \\
\hline Laboran & 6 \\
\hline Jumlah & 41 \\
\hline
\end{tabular}

Sumber : Kepegawaian UBP Karawang 2019 
Dari uraian di atas, penulis tertarik untuk menganalisis kepemimpinan terhadap kinerja tenaga kependidikan Universitas Buana Perjuangan Karawang.

\section{Rumusan Masalah}

Terdapat beberapa rumusan masalah yang diangkat dalam penelitian ini yaitu:

1. Bagaimana kepemimpinan di Universitas Buana Perjuangan Karawang?

2. Bagaimana kinerja tenaga kependidikan Universitas Buana Perjuangan Karawang?

3. Bagaimana pengaruh kepemimpinan terhadap kinerja tenaga kependidkan Universitas Buana Perjuangan Karawang ?

\section{Landasan Teori}

\section{Kepemimpinan}

Robin dan Judge (2009: 420-436) menjelaskan lima teori kepemimpinan, yakni (1) Teori sifat (Traith Teory); (2) Teori Perilaku (behavioral theory); (3) Teori Kontigensi (Contigency theory); (4) Leader- Member Exchange (LMX) Theory; dan (5) Teori Keputusan (Decision theory). Teori sifat kepemimpinan (trait theories of leadership) membedakan para pemimpin dari mereka yang bukan pemimpin dengan cara berfokus pada berbagai sifat dan karakteristik pribadi.

Pada dasarnya, semua orang bisa membuat definisi kepemimpinan. Prof. Dr. Siswoyo Haryono (2011:1) memaknai pemimpin sebagai kemampuan seseorang untuk mempengaruhi atau mengajak orang lain (pengikut atau anak buah) untuk mencapai tujuan kelompok atau organisasinya.

Selanjutnya, Prof. Dr. Siswoyo Haryono (2011:6) mengemukakan bahwa secara umum karakteristik yang diperlukan seorang pemimpin harus memiliki beberapa keistimewaan dalam hal kepribadiannya, diantaranya adaptable (mudah menyesuaikan diri), 
assertive (lugas), charismatic (berwibawa dan berkharisma), creative (banyak ide), decisive (tegas mengambil keputusan), dominant (menonjol diantara rekan rekannya), energetic (bertenaga dan berstamina tinggi, tidak mudah loyo), extraverted (berkepribadian terbuka), firendly (ramah terhadap siapa saja), honest (jujur), intelligent (cerdas), masculine (jantan), self-confident (percaya diri) dan wise (bijaksana). Sedangkan ciri ciri secara fisik seorang pemimpin yang ideal adalah athletic (atletis), attractive (menarik) dan tall (tinggi).

Malayu Hasibuan (1996:88) menjelaskan beberapa tipe kepemimpinan, yaitu 1) Kepimimpinan Otoriter, 2) Kepemimpinan Partisipatif, 3) Kepemimpinan Delegatif. Dapat dikatakan bahwa sebenarnya tidak ada kepemimpinan yang mutlak baik atau buruk yang penting asal tujuan tercapai dengan baik. Hal ini disebabkan karena kepemimpinan dipengaruhi oleh faktor-faktor: tujuan, pengikut (bawahan), organisasi, karakter pemimpin, dan situasi yang ada.

\section{Kinerja Pegawai Tenaga Kependidikan}

Menurut Veizal Rivai (2004: 309) mengemukakan kinerja merupakan perilaku yang nyata yang ditampilkan setiap orang sebagai prestasi kerja yang dihasilkan oleh karyawan sesuai dengan perannya dalam perusahaan.

Kinerja pegawai adalah hasil kerja secara kualitas dan kuantitas yang dicapai oleh seorang pegawai dalam melaksanakan tugasnya dengan tanggung jawab yang diberikan kepadanya (Mangkunegara, 2011). Fahmi (2013) menjelaskan bahwa kinerja adalah hasil yang diperoleh oleh suatu organisasi baik organisasi tersebut bersifat profit oriented dan non profit oriented yang dihasilkan selama satu periode tertentu.

Pengukuran kinerja merupakan suatu alat manajemen yang digunakan untuk meningkatkan kualitas pengambilan keputusan dan akuntabilitas. Pengukuran kinerja digunakan untuk penilaian atas keberhasilan/kegagalan pelaksanaan kegiatan/program/kebijakan sesuai dengan sasaran dan tujuan yang telah ditetapkan dalam rangka mewujudkan misi dan visi organisasi (Sedarmayanti, 2014). 
Menurut Moeheriono (2014:139) faktor penilaian adalah aspek-aspek yang diukur dalam proses penilaian kerja individu. Faktor penilaian tersebut terdiri dari empat aspek, yakni hasil kerja, perilaku, atribut dan kompetensi serta komparatif.

Menurut Mangkunegara (2002: 68), terdapat beberapa karakterstik kinerja pegawai yaitu:

1) Memiliki tanggung jawab pribadi yang tinggi

2) Berani mengambil dan menanggung resiko yang dihadapi

3) Memiliki tujuan yang realistis

4) Memiliki rencana kerja yang menyeluruh dan berjuang untuk merealisasi tujuannnya

5) Memanfaatkan umpan balik (feedback) yang konkrit dalam seluruh kegiatan kerja yang dilakukannya

6) Mencari kesempatan untuk merealisasikan rencana yang telah diprogramkan

Dimensi dan indikator kinerja diantaranya dikemukakan oleh Mangkunegara (2011:75)

Terdapat lima dimensi dan terbagi menjadi beberapa indikator diantaranya sebagai berikut:

1) Dimensi Kualitas Kerja, diukur dengan menggunakan tiga indicator:
a) Kemampuan
b) Keterampilan
c) Hasil kerja

2) Dimensi Kuantitas dan hasil Kerja, diukur dengan menggunakan dua indikator : 

a) Kerapihan
b) Ketelitian
c) Hasil Kerja

3) Dimensi Kerja Sama, yang terdiri dari dua indikator :
a) Jalinan kerja sama
b) Kekompakan

4) Dimensi Tanggung Jawab, yang terdiri dari dua indikator :
a) Tanggung Jawab Dalam Tugas
b) Pengambilan Keputusan

5) Dimensi Inisiatif, yang diukur dengan menggunakan satu indikator, yaitu Kemampuan

Menurut Robbins (2006: 260) terdapat enam indicator untuk mengukur kinerja pegawai secara individu, yaitu

1) Kualitas. Kualitas kerja diukur dari persepsi karyawan terhadap kualitas pekerjaan yang dihasilkan serta kesempurnaan tugas terhadap keterampilan dan kemampuan karyawan

2) Kuantitas. Merupakan jumlah yang dihasilkan dinyatakan dalam istilah seperti jumlah unit, jumlah siklus aktivitas yang diselesaikan.

3) Ketepatan waktu. Merupakan tingkat aktivitas diselesaikan pada awal waktu yang dinyatakan, dilihat dari sudat koordinasi dengan hasil output serta memaksimalkan waktu yang tersedia untuk aktivitas lain. 
4) Ekektivitas. Merupakan tingkat penggunaan sumber daya organisasi (tenaga, uang, teknologi, bahan baku) dimaksimalkan dengan maksud menaikkan hasil dari setiap unit dalam penggunaan sumber daya.

5) Kemandirian. Merupakan tingkat seorang karyawan yang nantinya akan dapat menjalankan fungsi kerjanya.

6) Komitmen kerja merupakan suatu tingkat dimana karyawan mempunyai komitmen dengan instansi dan tanggung jawab karyawan terhadap kantor.

Menurut Umar yang dikutip oleh Mangkunegara (2014 : 18) terdapat dua aspek atau dimensi standar kinerja karyawan dan kemudiandikembangkan menjadi beberapa indicator, yaitu :

1) Kuantitatif, meliputi :

a) Proses kerja dan kondisi pekerjaan

b) Waktu dalam bekerja

c) Jumlah kesalahan

d) Jumlah dan jenis pekerjaan

2) Kualitatif, meliputi :

a) Kualitas pekerjaan

b) Ketepatan waktu

c) Kemampuan dan keterampilan kerja

d) Kemampuan mengevaluasi

Simamora dalam Mangkunegara (2014 : 14) mengemukakan hal-hal yang dapat mempengaruhi kinerja yaitu :

1) Faktor Individu. Terdiri dari : 

a) Kemampuan dan keahlian
b) Latar belakang
c) Demografi

2) Faktor psikologis, terdiri dari:
a) Persepsi
b) Attitude
c) Personality
d) Pembelajaran
e) Motivasi

3) Faktor organisasi, terdiri dari:
a) Sumber daya
b) Kepemimpinan
c) Penghargaan
d) Struktur
e) Job Design

Tenaga kependidikan adalah anggota masyarakat yang mengabdikan diri dan diangkat untuk menunjang penyelenggaraan pendidikan. (UU No. 20 tahun 2003 pasal 1, Bab 1 Ketentuan umum). Tenaga Kependidikan Merupakan tenaga yang bertugas merencanakan dan melaksanakan administrasi, pengelolaan, pengembangan, pengawasan, dan pelayanan teknis untuk menunjang proses pendidikan pada satuan pendidikan. (UU No.20 Tahun 2003, Pasal 39 (1)). Tenaga kependidikan adalah pegawai yang ditempatkan sebagai 
tenaga penunjang pelaksanaan kegiatan akademik dan di luar kegiatan akademis (Peraturan Kepagawaian Universitas Buana Perjuangan Karawang Pasal 1 ayat 14). 


\section{Kerangka Pemikiran}

\begin{tabular}{|c|c|}
\hline Kepemimpinan (XI) & Kinerja Tenaga \\
\hline & Kependidikan (Y) \\
\hline
\end{tabular}

Gambar 1. Kerangka Penelitian

Sumber : Kajian Peneliti, 2019

\section{Metode Penelitian}

Penelitian ini menggunakan metodelogi pendekatan kuantitatif deskriptif verifikatif, yaitu untuk menganalisis pengaruh kepemimpinan terhadap kinerja tenaga kependidikan. Penelitian dilakukan di Universitas Buana Perjuangan Karawang dengan populasinya yaitu seluruh tenaga kependidikan Universitas Buana Perjuangan Karawang berjumlah 41 orang. Menurut Arikunto (2005:120), mengingat jumlah populasinya kurang dari 100 orang maka selulurh populasi dijadikan sampel dalam penelitian ini yakni sebanyak 41 orang. Data yang digunakan berupa data primer (melalui interview, observasi serta pengisian kuesioner) dan data sekunder (melalui studi kepustakaan). Setelah data diperoleh, maka dilakukan analisis statistik deskriptif untuk menjelaskan variabel yang diteliti, kemudian dilanjutkan analisis regresi korelasi dan analisis determinasi menggunakan program SPSS 16.0.

\section{Hasil dan Pembahasan}

\section{Uji Validitas dan Reliabilitas}


Dari hasil uji validitas kuesioner untuk variabel kepemimpinan (variabel X) dari penelitian ini dinyatakan valid (Tabel 1). Kemudian untuk variabel kinerja tenaga kependidikan, didapatkan hasil bahwa pertanyaan kuesioner nomor 1 tidak valid $(0,344<0,444)$, sedangkan pertanyaan kuesioner yang lainnya valid (Tabel.2), maka pertanyaan nomor 1 tidak digunakan dalam penelitian ini. Setelah dilakukan uji validitas, maka kemudian kuesioner penelitian di uji reliabilitas. Hasilnya menunjukkan bahwa kuesioner penelitian ini realibel karena nilai cronbach's alpha lebih besar dibandingkan nilai tabel r $(0,920>0,444)$ (Tabel.3). 
Tabel 1. Hasil Uji Validitas Variabel Kepemimpinan

Item-Total Statistics

\begin{tabular}{|l|r|r|r|r|}
\hline & $\begin{array}{c}\text { Scale Mean if } \\
\text { Item Deleted }\end{array}$ & $\begin{array}{c}\text { Scale } \\
\text { variance if } \\
\text { Item Deleted }\end{array}$ & $\begin{array}{c}\text { Corrected } \\
\text { Item-Total } \\
\text { Correlation }\end{array}$ & $\begin{array}{c}\text { Cronbach's } \\
\text { Alpha if Item } \\
\text { Deleted }\end{array}$ \\
\hline X1 & 49.65 & 30.029 & .825 & .910 \\
$\times 2$ & 49.40 & 30.674 & .683 & .914 \\
$\times 3$ & 49.40 & 30.674 & .683 & .914 \\
$\times 4$ & 49.85 & 30.239 & .571 & .918 \\
$\times 6$ & 49.80 & 29.432 & .679 & .914 \\
$\times 7$ & 49.85 & 30.450 & .541 & .919 \\
$\times 8$ & 49.65 & 31.397 & .568 & .917 \\
$\times 9$ & 49.45 & 31.839 & .572 & .917 \\
$\times 10$ & 49.60 & 30.147 & .816 & .910 \\
$\times 11$ & 49.50 & 31.105 & .545 & .918 \\
$\times 12$ & 49.65 & 31.503 & .548 & .917 \\
$\times 13$ & 49.50 & 31.211 & .528 & .918 \\
$\times 14$ & 49.80 & 29.853 & .718 & .912 \\
$\times 15$ & 49.75 & 29.566 & .756 & .911 \\
\hline
\end{tabular}

Sumber: Hasil olah data dengan SPSS, 2019

Tabel 2. Hasil Uji Validitas Variabel Kinerja

Item-Total Statistics

\begin{tabular}{|l|r|r|r|r|}
\hline & $\begin{array}{c}\text { Scale Mean if } \\
\text { Item Deleted }\end{array}$ & $\begin{array}{c}\text { Scale } \\
\text { Variance if } \\
\text { Item Deleted }\end{array}$ & $\begin{array}{c}\text { Corrected } \\
\text { Item-Total } \\
\text { Correlation }\end{array}$ & $\begin{array}{c}\text { Cronbach's } \\
\text { Alpha if Item } \\
\text { Deleted }\end{array}$ \\
\hline$Y 1$ & 49.25 & 26.724 & .344 & .928 \\
$Y 2$ & 49.35 & 25.292 & .633 & .919 \\
$Y 4$ & 49.30 & 24.642 & .765 & .915 \\
$Y 5$ & 49.35 & 25.187 & .654 & .919 \\
$Y 6$ & 49.20 & 24.905 & .726 & .916 \\
$Y 7$ & 49.25 & 24.724 & .752 & .916 \\
$Y 8$ & 49.40 & 26.253 & .446 & .925 \\
$Y 9$ & 49.30 & 25.274 & .633 & .919 \\
$Y 10$ & 49.25 & 24.724 & .752 & .916 \\
$Y 11$ & 49.15 & 25.924 & .529 & .922 \\
$Y 12$ & 49.20 & 24.695 & .771 & .915 \\
$Y 13$ & 49.20 & 24.800 & .749 & .916 \\
$Y 14$ & 49.30 & 25.274 & .633 & .919 \\
$Y 15$ & 49.40 & 25.621 & .575 & .921 \\
\hline
\end{tabular}


Sumber: Hasil olah data dengan SPSS, 2019

Tabel 3. Hasil Uji Reliabilitas Kuesioner

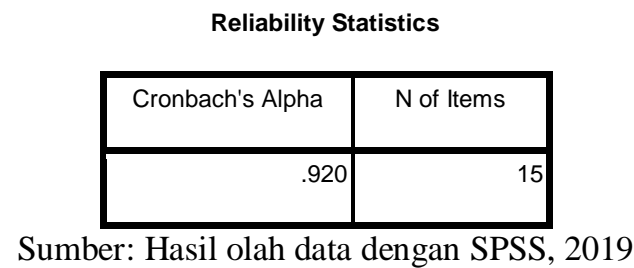

\section{Analisis Statistik Deskriptif}

Variabel kepemimpinan sebagai variabel independent dan variabel dependen dalam penelitian ini yaitu kinerja tenaga kependidikan diuji secara statistik deskriptif. Pengujian dengan statistik deskriptif akan memberikan gambaran atau deskripsi data yang dilihat melalui nilai minimum, maksimum, rata-rata (mean) dan standar deviasi. Berikut ini merupakan tabel hasil pengujian statistik deskriptif atas variabel-variabel tersebut.

Tabel 4. Hasil Analisis Statistik Deskriptif

\begin{tabular}{|l|c|c|c|c|c|}
\hline \multicolumn{7}{|c|}{ Descriptive Statistics } \\
\hline & N & Minimum & Maximum & Mean & Std. Deviation \\
\hline Kepemimpinan & 41 & 40 & 60 & 54,90 & 4,742 \\
\hline $\begin{array}{l}\text { Kinerja Tenaga } \\
\text { Kependidikan }\end{array}$ & 41 & 41 & 60 & 52,37 & 4,841 \\
\hline Valid N (listwise) & 41 & & & & \\
\hline
\end{tabular}

Sumber: Hasil olah data dengan SPSS, 2019 
Tabel 4 di atas menunjukkan bahwa jumlah data yang digunakan dalam penelitian ini adalah 41 sampel yang berasal dari tenaga kependidikan UBP Karawang. Kemudian analisis statistik deskriptif pada masing-masing variabel akan dijabarkan sebagai berikut:

\section{Kepemimpinan}

Variabel independen pada penelitian ini adalah kepemimpinan. Hasil analisis menggunakan statistik deskriptif terhadap variabel kepemimpinan menunjukkan nilai minimum sebesar 40 dan nilai maksimum sebesar 60. Kemudian nilai rata-rata yang diperoleh sebesar 54,90 dengan nilai standar deviasi sebesar 4,742.

\section{Kinerja Tenaga Kependidikan}

Variabel dependen pada penelitian ini adalah kinerja tenaga kependidikan. Hasil analisis menggunakan statistik deskriptif terhadap variabel kinerja tenaga kependidikan menunjukkan nilai minimum sebesar 41 dan nilai maksimum sebesar 60 . Kemudian nilai rata-rata yang diperoleh sebesar 52,37 dengan nilai standar deviasi sebesar 4,841 .

\section{Analisis Regresi Korelasi}

Berdasarkan hasil analisis, didapatkan antara variabel kepemimpinan dengan kinerja tenaga kependidikan menunjukkan hubungan yang sangat rendah $(0,366)$ dan berpola positif, artinya semakin baik kepemimpinan maka kinerja tenaga kependididkan juga akan semakin meningkat. Dan sebaliknya, jika kepemimpinan tidak baik maka kinerja tenaga kependidikan akan menurun. Didapatkan pula nilai koefisien determinasi $\left(\mathrm{R}^{2}\right)=0,134$ yang artinya variabel kepemimpinan menjelaskan kinerja tenaga kependidikan sebesar 13,4\%, sedangkan sisanya dipengaruhi oleh variabel lain diluar penelitian ini. Hasil uji statistik didapatkan ada hubungan antara kepemimpinan terhadap kinerja tenaga kependidikan (Pvalue $<0,05)$. Persamaan regresi linier pada penelitian ini adalah $\mathrm{Y}=31,832+0,374 \mathrm{X}$.

Tabel 5. Hasil Analisis Regresi Korelasi dan Determinasi 


\begin{tabular}{|c|c|c|c|c|}
\hline Variabel & $\mathbf{R}$ & $\mathbf{R}^{2}$ & Persamaan Garis & P-value \\
\hline $\begin{array}{c}\text { Kepemimpinan terhadap } \\
\text { kinerja tenaga kependidikan }\end{array}$ & 0,366 & 0,134 & $\begin{array}{c}\text { Y }=31,832+0,374 \text { Kinerja Tenaga } \\
\text { Kependidikan }\end{array}$ & 0,018 \\
\hline
\end{tabular}

Sumber: Hasil olah data dengan SPSS, 2019

\section{Daftar Pustaka}

Buku Cetak:

A.A. Anwar Prabu Mangkunegara, 2000. Manajemen Sumber Daya Manusia, Bandung. PT. Remaja Rosdakarya.

--------- 2002. Manajemen Sumber Daya Manusia. Bandung. PT. Remaja Rosda Karya 2011. Manajemen Sumber Daya Mansia Perusahaan. Bandung. PT. Remaja Rosda Karya

2014. Manajemen Sumber Daya Mansia Perusahaan. Bandung. PT. Remaja Rosda Karya

Ardana, Komang dkk. 2000. Perilaku Organisasi. Yohyakarta. Graha Ilmu

Ambar Teguh Sulistiyani. 2003. Manajemen dan Sumber Daya Manusia: Konsep dan Pengembangan Dalam Konteks Organisasi Publik. Yogyakarta. Graha Ilmu Cushway, Barrt. 2002. Human Rosource Management. Jakarta. PT. Gramedia Fahmi, Irham. 2013. Manajemen Kinerja, Teori dan Aplikasi. Bandung. Alfabeta Gibson, et al. 2009. Organissi, edisi ke-5. Jakarta. Erlangga

Hasibuan, Malayu. 2001. Manajemen Sumber Daya Manusia: Pengertian Dasar dan Masalah. Jakarta. PT. Toko Gunung Agung 1996. Manajemen Dasar, Pengertian dan Masalah. Edisi ke-2. Jakarta. PT. Toko Gunung Agung 
Kartono Kartini. 1992. Pemimpin dan Kepemimpinan. Jakarta. PT. Raja Grafindo Persada.

Mink. 1993. Seri Manajemen Sumber Daya Manusia （Kinerja/Performance). Jakarta. PT. Elexmedia Komputindo.

Moeheriono, 2014. Pengukuran Kinerja Berbasis Kompetensi. Bogor. Ghalia Indonesia

Mintzberg, Henry. 2004. Structure in Five, Designing Effective Organization. New Jersey. Prantice Hall.

Robbins, Stephan P. 2006. Perilaku Organisasi. PT. Indeks. Kelompok Gramedia. Jakarta

Robbins, Stephen, 2006. Perilaku Organisasi. (Alih Bahasa Drs. Benjamin Molan). Ed. Bahasa Indonesia. Klaten. PT. Intan Sejati

Richard, L. Daft. 2005. Management. Jakarta. Erlangga

Siswoyo Haryono, 2001. Intisari Teori Kepemimpinan. Bekasi. PT. Intermedia Personalia Utama

Sedarmayanti, 2014. Sumber Daya Mansia dan Produktivitas Kerja. Jakarta. Mandar Maju.

Veithzal Rivai. 2004. Manajemen Sumber Daya Manusia Untuk Perusahaan: Dari Teori ke Praktik. Jakarta. PT. Raja Grafindo Persada

Yuki, Gary A. 2005. Kepemimpinan Dalam Organisasi, edisi kelima. Jakarta. PT. Indeks

Jurnal:

Journal.lppmunindra.ac/id/index.php//JABE/article/download/1767/1369

Journal.unair.ac.id/ download-fullpapers-ln9b617af301full.pdf

Website:

https://media.neliti.com/media/publications/256948-kepemimpinan-dalam-budaya- organisasi- 
8826321c.pdf 